\title{
Chemical characterisation and allelopathic potential of essential oils from leaves and rhizomes of white ginger ${ }^{1}$
}

\author{
Caracterização química e potencial alelopático de óleos essenciais de folhas e \\ rizomas da planta "lírio-do-brejo"
}

\author{
Cíntia Alvarenga Santos Fraga Miranda ${ }^{2}$, Maria das Graças Cardoso ${ }^{3 *}$, Maria Laene Moreira Carvalho², Ana \\ Cristina Silva Figueiredo ${ }^{4}$ e Juliana de Andrade $^{5}$
}

\begin{abstract}
Essential oils have the potential to be used as bioherbicides, and possess the advantage of their biodegradability, high structural diversity and reduced natural resistance to weeds. The essential oils of the leaves and rhizomes of Hedychium coronarium, an exotic invasive plant adapted to different regions of Brazil, were extracted by hydrodistillation and characterised chemically by Gas-Liquid Chromatography and Gas-Liquid Chromatography/Mass Spectrometry. Allelopathic activity was determined using methodologies that evaluate the effects of volatility and direct contact on seed germination and seedling vigour in the lettuce. The major constituents of the essential oil from the leaves were $\beta$-pinene (46.9\%), $\alpha$-pinene $(19.2 \%)$ and $\beta$-caryophyllene (13.2\%) and from the rhizomes, $\beta$-pinene (41.5\%), 1.8-cineole (23.6\%) and $\alpha$-pinene (13.1\%). When analysing the volatile effects of the essential oils, it was seen that their concentration did not affect seedling first germination count or total germination. The essential oil from the rhizomes was more effective than the essential oil from the leaves in reducing seedling response for SGI, dry weight, and length of the roots and shoots. When evaluating the effect of direct contact with the essential oils, it was seen that both oils reduced the response of all the variables under evaluation, and that in addition, the oil from the rhizomes caused greater reductions than that from the leaves, again for all variables. These results can be attributed to the higher levels of monoterpenes present in the essential oil from the rhizomes, mainly the presence of 1.8-cineole.
\end{abstract}

Key words: Volatile oils. Hedychium coronarium. Allelopathy.

RESUMO - Os óleos essenciais apresentam potencial para serem empregados como bioherbicidas, possuindo vantagens em função da sua biodegradabilidade, elevada diversidade estrutural e reduzida resistência natural às plantas daninhas. Os óleos essenciais das folhas e dos rizomas de Hedychium coronarium, planta invasora exótica adaptada a diferentes regiões do Brasil, foram extraídos por hidrodestilação e caracterizados quimicamente por Cromatografia Gás-Líquido e Cromatografia Gás-Líquido/Espectrometria de Massas. As atividades alelopáticas foram determinadas pelas metodologias que avaliam os efeitos voláteis e o contato direto dos mesmos sobre a germinação de sementes e vigor de plântulas de alface. Os constituintes majoritários do óleo essencial das folhas foram o $\beta$-pineno (46,9\%), o $\alpha$-pineno (19,2\%) e o $\beta$-cariofileno (13,2\%) e o dos rizomas, o $\beta$-pineno $(41,5 \%)$, o 1,8-cineol $(23,6 \%)$ e o $\alpha$-pineno $(13,1 \%)$. Analisando os efeitos voláteis dos óleos essenciais, observou-se que o aumento das concentrações dos mesmos não alterou a primeira contagem de plântulas germinadas e a germinação total. Em relação ao IVG, à massa seca e ao comprimento das partes radiculares e aéreas das plântulas, o óleo essencial dos rizomas foi mais efetivo que o óleo essencial das folhas nas reduções da resposta das variáveis. Ao avaliar o efeito do contato direto dos óleos essenciais observou-se que ambos reduziram a resposta de todas as variáveis avaliadas e que, adicionalmente, o óleo dos rizomas provocou reduções superiores à do óleo das folhas em todas as variáveis. Estes resultados podem ser atribuídos ao maior conteúdo monoterpênico presente no óleo essencial dos rizomas, destacando-se a presença do 1,8-cineol.

Palavras-chave: Óleos voláteis. Hedychium coronarium. Alelopatia.

DOI: $10.5935 / 1806-6690.20150038$

*Autor correspondência

${ }^{1}$ Recebido para publicação 13/02/2014; aprovado em 06/03/2015

Part Doctoral Thesis of the first author presented in Graduate Program of Agrochemical, DQI/UFLA

${ }^{2}$ Departament of Agriculture, Federal University of Lavras/DQI/UFLA, Lavras-MG, Brazil, 37.200-000 cintiafmiranda@yahoo.com.br, mlaenemc@dag.ufla.br

${ }^{3}$ Departament of Chemical/Federal University of Lavras/DQI/UFLA, Lavras-MG, Brazil, 37.200-000, mcardoso@ dqi.ufla.br

${ }^{4}$ Centro de Estudos do Ambiente e do Mar Lisboa, Faculdade de Ciências, Universidade de Lisboa, CBV, DBV, Lisboa, Portugal, 17.49-016, acsf@fc.ul.pt

5ós-Graduate Program of Agrochemical, Federal University of Lavras, DQI/UFLA, Lavras-MG, Brazil, 37.200-000, juandrade_quimica@yahoo.com.br 


\section{INTRODUCTION}

In agricultural areas, the control of weeds is carried out mainly with the use of synthetic herbicides, which although efficient from a functional point of view, cause environmental damage as well as often targeting resistant species (SOUZA FILHO et al., 2006).

According to Duke, Romagni and Dayan (2000), chemical weed control needs to be dynamic and innovative: the use of natural products being an economical and ecologically viable alternative. Among the substances of natural origin, essential oils may be employed as bioherbicides, which although structurally more complex than synthetic herbicides, originate exclusively from the secondary metabolism of plant species, and in addition to being biodegradable, display high structural diversity and consequently do not induce a natural resistance in the weeds.

Essential oils are complex mixtures of volatile compounds, which are produced in such plant organs as the flowers, leaves, seeds, rhizomes and outer surfaces, among others. They are made up of phenylpropanoids and terpenoids. Among the terpenoids, Silva et al. (2009) mainly highlight the monoterpenes, which, besides comprising a class of substances present in larger quantities in essential oils, have various functions in plants, such as that of phytoalexins, hormones, allelochemicals, repellents of insect and micro-organisms, the attraction of pollinators and defense against herbivores.

Standing out among the invasive species that produce essential oils is Hedychium coronarium, a monocot aquatic macrophyte of the Zingiberaceae family, originally from tropical Asia and now adapted and found throughout America. Because it is commonly found in swamp areas, it is popularly known in Brazil as "swamp lily (lírio-do-brejo), "white ginger" or "butterfly lily" (MARTINS et al., 2010). Due to its rapid growth and dispersion, it is considered an exotic weed. It is found in various regions of Brazil, mainly the Cerrado, the coastal forests of the Serra do Mar mountains, the riparian jungle of Araucária, the coastal and inland forests of the state of Bahia, the Caatinga and the Atlantic forest of Alto Paraná, replacing the original vegetation and causing damage (ZENNI; ZILLER, 2011).

Invasive species are known for their allelopathic potential, promoting deleterious biochemical interactions between higher plants. Research by Barbosa et al. (2007), Rosado et al. (2009), Silva et al. (2009), Souza Filho et al. (2006), Souza Filho et al. (2009), show that various natural substances have an allelopathic effect, including many compounds present in essential oils, such as monoterpenes and sesquiterpenes, which may act by inhibiting seed germination and/or affecting plant vigour. Due to these negative effects on native species, the weeds become a real problem in places where they proliferate (SANTOS; PEDRALLI; MEYER, 2005).
This work aimed to characterise chemically and evaluate the allelopathic potential of the essential oils of the leaves and fresh rhizomes of $H$. coronarium, using methodologies that assess their volatile effect and direct contact on seed germination and vigour in lettuce seedlings.

\section{MATERIALS AND METHODS}

\section{Collecting the Plant Material}

Plants of Hedychium coronarium were collected on the campus of the Federal University of Lavras (UFLA) $\left(21^{\circ} 13^{\prime} 37^{\prime \prime} \mathrm{S}, 44^{\circ} 58^{\prime} 20^{\prime \prime} \mathrm{W}\right)$, at around 0800 on 25 February 2012. Young leaves (rib and lamina) and rhizomes of adult plants in full bloom were harvested. The species was identified by Dr Mariana Esteves Mansanares from the Department of Biology at UFLA, and an exsiccata deposited in the ESAL Herbarium of UFLA, under record no 26942.

\section{Extracting the Essential Oils}

The essential oils of the rhizomes and leaves of the species were obtained by hydrodistillation, following a methodology described by the Agência Nacional de Vigilância Sanitária (2010) and using a modified Clevenger apparatus adapted to a round-bottom flask with a capacity of 4 litres, for a period of 2 hours in order to obtain the hydrolate, which was centrifuged at $965.36 g$ for 5 minutes. The essential oils were then separated with a Pasteur pipette, placed into vials of amber glass and stored at $4{ }^{\circ} \mathrm{C}$.

\section{Determining the moisture and yield of the essential oils}

Five $\mathrm{g}$ of leaves or chopped fresh rhizomes in $70 \mathrm{ml}$ of cyclohexane were placed into a round-bottom flask of $250 \mathrm{~mL}$ capacity coupled to a glass Dean-Stark collector. The flask was placed into a heating mantle for 2 hours at a temperature of $81 \pm 1{ }^{\circ} \mathrm{C}$ and the volume of water measured. From this volume, the moisture-free weight of the plants was calculated and used to determine the levels of essential oils present in the leaves and rhizomes of Hedychium coronarium, expressed on a moisture-free plant basis (MFB), in $\mathrm{w} \mathrm{w}^{-1}$ (PIMENTEL et al., 2006).

\section{Identifying the constituents of the essential oils}

For the analysis by gas-liquid chromatography coupled with mass spectrometry (GLC-MS), a Perkin Elmer Autosystem XL chromatograph was used, equipped with a DB-1 fused-silica column ( $30 \mathrm{~m} \times 0.25 \mathrm{~mm}$ ID, $0.25 \mu \mathrm{m}$ film thickness; from J \& W Scientific Inc.), coupled to a Perkin Elmer TurboMass mass spectrometer (software version 4.1). The oven temperature was programmed from 45 to $175^{\circ} \mathrm{C}$ increasing by $3^{\circ} \mathrm{C} \mathrm{min}^{-1}$, and then by $15{ }^{\circ} \mathrm{C} \mathrm{min}-1$ to $300{ }^{\circ} \mathrm{C}$. On reaching $300{ }^{\circ} \mathrm{C}$, the temperature was kept constant for $10 \mathrm{~min}$; transfer line temperature of $280{ }^{\circ} \mathrm{C}$, ionisation chamber temperature of $220{ }^{\circ} \mathrm{C}$, the carrier 
gas (helium) adjusted to a linear velocity of $30 \mathrm{~cm} \mathrm{~s}^{-1}$ and the flow distribution ratio to $1: 40$.

Identification of the compounds was determined by a comparison of the retention indices for the $\mathrm{C}_{9}-\mathrm{C}_{21} \mathrm{n}$ alkanes and mass spectra, with the commercial standards and reference compounds present in oils existing in the laboratory. A comparison was also made with the library of mass spectra developed in the Laboratory of the Centre for Plant Biotechnology, at the School of Science of the University of Lisbon (MENDES et al., 2011).

\section{Quantifying the constituents of the essential oils}

The essential oils were analysed by gas-liquid chromatography (GLC) on a Perkin Elmer 8700 gas chromatograph equipped with two flame ionization detectors (FID), a data processing system and an injector in which two columns of different polarities were installed, each consisting of a DB-1 of fused silica with an immobilised methyl silicone phase ( $30 \mathrm{~m} \times 0.25$ $\mathrm{mm}$ ID, $0.25 \mu \mathrm{m}$ film thickness, from J \& W Scientific Inc.). The oven temperature was programmed from 45 to $175^{\circ} \mathrm{C}$, increasing by $3{ }^{\circ} \mathrm{C} \mathrm{min}{ }^{-1}$, and then by $15^{\circ} \mathrm{C} \mathrm{min}^{-1}$ to $300{ }^{\circ} \mathrm{C}$. On reaching $300{ }^{\circ} \mathrm{C}$, the temperature was kept constant for $10 \mathrm{~min}$. The temperature of the injector and detectors was 290 and $280{ }^{\circ} \mathrm{C}$ respectively. Hydrogen was used as the carrier gas, adjusted to a linear velocity of $30 \mathrm{~cm} \mathrm{~s}^{-1}$, with a flow distribution ratio of 1:50.

The percentage composition of the oils was determined by integration of the peak areas without the use of correction factors. The values shown correspond to the mean value of two injections.

\section{Allelopathic activity of the essential oils}

The allelopathic potential of the essential oils was evaluated in two bioassays, the first, to assess the volatile effect and the second, the direct contact of these oils on germination in the lettuce seeds (cultivar Regina SF 3500). The solutions were prepared with $0.5 \mathrm{~mL}$ of each essential oil emulsified with Tween 80 in a ratio of 1:1 $\left(\mathrm{v} \mathrm{v}^{-1}\right)$ and dissolved in distilled water to give a stock solution at a concentration of $1 \%$. The other concentrations $\left(0.1\right.$ and $\left.0.01 \% \mathrm{v} \mathrm{v}^{-1}\right)$ were prepared by dilution. Water and a solution of Tween 80 at $1.0 \% \mathrm{v} \mathrm{v}^{-1}$ were used for the controls (SILVA et al., 2009). The tested solutions were added only at the start of the bioassays, after which only distilled water was added when necessary (SOUZA FILHO et al., 2009). In both bioassays, the seeds were placed into an acrylic gerbox (11 x $11 \times 4 \mathrm{~cm})$, with two sterilised sheets of blotting paper as substrate. Fifty seeds were distributed in each box, giving 200 seeds per treatment, and kept in a growth chamber (BOD) at $20 \pm 1{ }^{\circ} \mathrm{C}$ under a photoperiod of 12 hours. In the direct-contact method, the blotting paper was soaked with solutions of the essential oils at different concentrations in amounts equal to 2.5 times its dry weight (BRASIL, 2009).
To evaluate the volatile effect, distilled water was added to the paper substrate in amounts equal to 2.5 times its dry weight (BRAZIL, 2009). Three $\mathrm{mL}$ of each solution were also placed onto two sheets of filter paper fixed to the cover of the box, avoiding any direct contact of the solution under test with the seeds (SOUZA FILHO et al., 2009).

Germination was monitored for seven days from the start of the test by daily counts of the lettuce seedlings, the results being expressed as a percentage of normal seedlings (BRASIL, 2009).

Seed vigour was determined by the following variables: first germination count (\%); evaluation of germination in normal seedlings on the fourth day after sowing (BRASIL, 2009); Germination Speed Index (GSI), calculated according to Maguire (1962); average lengths for roots and shoots of the seedlings $(\mathrm{mm})$ on the seventh day, taken with the aid of a millimeter rule, with mean results expressed in millimeters (BRASIL, 2009); measurement of seedling dry weight $(\mathrm{g})$, carried out in Kraft paper bags in an incubator at $60{ }^{\circ} \mathrm{C}$ to constant weight. After that, each replication was weighed and the averages calculated, with the results expressed in grams (KRZYZANOWSKI; VIEIRA; FRANÇA NETO, 1999).

\section{Statistical Analysis}

The experimental design used for both methodologies was completely randomised in a $4 \times 2$ factorial scheme (4 concentrations x 2 essential oils), with four replications. As they are oils extracted from different parts of the same botanical species, the essential oils were compared to each other, unlike in the other methodologies where, due to having chemical mechanisms that are known to be different, the oils are not compared. The quantitative variables significant by F-test were subjected to regression analysis. The data were analysed by the Variance Analysis System for Balanced Data (Sisvar) statistical software, as per Ferreira (2011).

\section{RESULTS AND DISCUSSION}

The essential oils from different parts of $H$. coronarium gave yields of $0.30 \%\left(\mathrm{w} \mathrm{w}^{-1}\right)$ for the leaves and $1.02 \%\left(\mathrm{w} \mathrm{W}^{-1}\right)$ for the rhizomes, with $99.3 \%$ of the chemical constituents of the essential oil from the leaves being identified and $99.2 \%$ from the rhizomes (Table 1):

The major constituents of the oil from the leaves were monoterpenes $\beta$-pinene (46.9\%), $\alpha$-pinene (19.2\%) and the sesquiterpene $\beta$-caryophyllene (13.2\%), and from the rhizomes, the monoterpenes $\beta$-pinene (41.5\%), 1,8-cineole (23.6\%) and $\alpha$-pinene (13.1\%). Santos et al. (2010) studied the essential oils from the leaves and fresh rhizomes of $H$. 
Table 1 - Percent composition of the essential oils isolated from the leaves and rhizomes of $H$. coronarium

\begin{tabular}{|c|c|c|c|}
\hline \multirow{2}{*}{ Component } & \multirow{2}{*}{ RI } & \multicolumn{2}{|c|}{ Constituent $\%$} \\
\hline & & Leaves & Rhizomes \\
\hline Tricyclene & 921 & & $\mathrm{t}$ \\
\hline$\alpha$-Thujene & 924 & 0.1 & $\mathrm{t}$ \\
\hline$\alpha$-Pinene & 930 & 19.2 & 13.1 \\
\hline Camphene & 938 & 0.1 & 1.2 \\
\hline Sabinene & 958 & 4.3 & 4.1 \\
\hline$\beta$-Pinene & 963 & 46.9 & 41.5 \\
\hline$\beta$-Myrcene & 975 & 1.1 & 1.2 \\
\hline$\alpha$-Phellandrene & 995 & 0.1 & 1.8 \\
\hline$\delta$-3-Carene & 1000 & & 1.8 \\
\hline$\alpha$-Terpinene & 1002 & 0.2 & 0.5 \\
\hline p-Cymene & 1003 & 0.1 & 0.3 \\
\hline 1.8-Cineole & 1005 & 7.8 & 23.6 \\
\hline Limonene & 1009 & 2.8 & 3.5 \\
\hline cis- $\beta$-Ocimene & 1017 & $\mathrm{t}$ & \\
\hline trans- $\beta$-Ocimene & 1027 & 0.2 & $\mathrm{t}$ \\
\hline$\gamma$-Terpinene & 1035 & 0.6 & 0.9 \\
\hline trans-Sabinene hydrate & 1037 & $\mathrm{t}$ & $\mathrm{t}$ \\
\hline Terpinolene & 1064 & 0.1 & 0.3 \\
\hline Linalool & 1074 & & $\mathrm{t}$ \\
\hline Borneol & 1134 & 0.1 & 0.6 \\
\hline Terpinen-4-ol & 1148 & 0.4 & 1.3 \\
\hline$\alpha$-Terpineol & 1159 & 0.2 & 1.7 \\
\hline Bornyl acetate & 1265 & $\mathrm{t}$ & 0.6 \\
\hline$\delta$-Elemene & 1332 & 0.3 & \\
\hline$\alpha$-Terpenyl acetate & 1334 & & 0.3 \\
\hline$\beta$-Elemene & 1388 & 0.1 & \\
\hline$\beta$-Caryophyllene & 1414 & 13.2 & 0.5 \\
\hline Guaia-6.9-diene & 1447 & $\mathrm{t}$ & \\
\hline$\alpha$-Humulene & 1447 & 0.5 & \\
\hline trans- $\beta$-Farnesene & 1455 & $\mathrm{t}$ & 0.1 \\
\hline$\gamma$-Muurolene & 1469 & $\mathrm{t}$ & \\
\hline$\gamma$-Cadinene & 1500 & & $\mathrm{t}$ \\
\hline (trans,trans)- $\alpha$-Farnesene & 1500 & $\mathrm{t}$ & 0.3 \\
\hline$\delta$-Cadinene & 1500 & $\mathrm{t}$ & 0.1 \\
\hline Isocaryophyllene & 1528 & $\mathrm{t}$ & \\
\hline Germacrene-B & 1533 & 0.1 & \\
\hline trans-Nerolidol & 1549 & 0.1 & \\
\hline$\beta$-Caryophyllene oxide & 1561 & 0.6 & \\
\hline Viridiflorol & 1569 & $\mathrm{t}$ & \\
\hline$\alpha$-Cadinol & 1626 & & $\mathrm{t}$ \\
\hline Phytol acetate & 2047 & $\mathrm{t}$ & \\
\hline
\end{tabular}

RI, Retention Index tabulated for a series of n-alkanes $\left(\mathrm{C}_{9}-\mathrm{C}_{21}\right)$ in a DB-1 column; t, trace $(<0.05 \%)$ 
coronarium collected in the Atlantic Forest of southeastern Brazil and obtained a yield of $0.68 \%\left(\mathrm{w} \mathrm{w}^{-1}\right)$ and $0.20 \%$ $\left(\mathrm{W} \mathrm{w}^{-1}\right)$ in MFB respectively. As main components of the essential oil from the leaves they found $\beta$-caryophyllene (43.0\%), caryophyllene oxide (12.1\%) and $\beta$-pinene (11.6\%), while in the rhizomes, 1,8 -cineole $(34.8 \%)$, $\beta$-pinene $(16.7 \%)$ and $\alpha$-terpineol $(13.1 \%)$. When evaluating the chemical composition of the essential oil from the rhizomes of the same botanical species collected in India, Prakash et al. (2010) identified $98.7 \%$ of the chemical constituents, with the major constituents being linalool (29.3\%), limonene (20.3\%), transmeta-mentha-2,8-diene (12.9\%) and $\gamma$-terpinene (8.9\%). This variability in the chemical yields and compositions seen in the essential oils of $H$. coronarium in the present study and in the research conducted by Prakash et al. (2010) and Santos et al. (2010), is possibly due to differences in the crop-growing areas and times of collection, the crop cycle and in edaphoclimatic factors (GOBBO-NETO; LOPES, 2007).

When analysing the volatile effect of the essential oils from different parts of $H$. coronarium, it was seen that an increase in concentration of the oils did not alter the first count of germinated seedlings or the total germination, with respective mean percentage values of 91.5 and $95 \%$ for the essential oil from the leaves, and 91 and $94 \%$ for the essential oil from the rhizomes (Figure 1).

None of the concentrations of the essential oil extracted from the leaves influenced the response of the GSI and root length variables of the lettuce seedlings, maintaining mean values for the GSI of 74.9 and seedling root length of $37.3 \mathrm{~mm}$. Different trends were displayed by the essential oil extracted from the rhizomes when these variables were evaluated, which at its highest concentration $\left(1 \% \mathrm{v} \mathrm{v}^{-1}\right)$ caused a decrease in response of the GSI from 75.9 to 65.8 and the length of the rootlets from 38.5 to $35.7 \mathrm{~mm}$. For the dry weight and shoot length of the seedlings, the oil from the rhizomes was more effective than that from the leaves in reducing variable response. A $1 \%$ concentration of the essential oil from the leaves caused a decrease in dry matter from 0.0375 to $0.0365 \mathrm{~g}$, with the oil from the rhizomes reducing the response of this variable from 0.0365 to $0.0345 \mathrm{~g}$. Assessing the influence of the volatile effect of the essential oils on shoot length in the lettuce seedlings, a reduction was seen of 17.6 to $16.5 \mathrm{~mm}$ caused by the oil from the leaves, and from 18.0 to $16.8 \mathrm{~mm}$ caused by the oil from the rhizomes (Figure 2).

Silva et al. (2009) claim that allelochemicals may not significantly alter seed germination or affect germination speed and timing, which may explain the fact that the volatile effect of the essential oils under evaluation does not affect the first count of germinated seedlings or total seedling germination, but does alter the GSI, dry weight, shoot length and root length of the seedlings. The observed results suggest that the low activity seen when evaluating the volatile effect may be due to the fact that the atmosphere formed inside the gerbox has a lower concentration of these essential oils, with less contact with the seeds and a consequently smaller inhibitory effect.

When evaluating the effect of direct contact of the essential oils on the germination and vigour of the lettuce seedlings, it was seen that both of the essential oils reduced the response of all the variables under test, and that in addition the oil from the rhizomes caused a greater reduction in all the variables than the oil from the leaves. Among these variables, first count and final germination where proportionally less affected by an increase in concentration. A $1 \%$ concentration of the oil from the leaves reduced first germination count from 91.5 to $82 \%$ and final germination from 96 to $90.5 \%$, while the same concentration of the oil from the rhizomes reduced initial seed germination from 91 to $77 \%$ and final seed germination from 95.5 to $84 \%$ (Figure 3).

Figure 1 - Regression equations of the response variables first germination count and total germination, for concentrations of essential oils extracted from the leaves and rhizomes of $H$. coronarium, evaluated with volatile-effect methodology
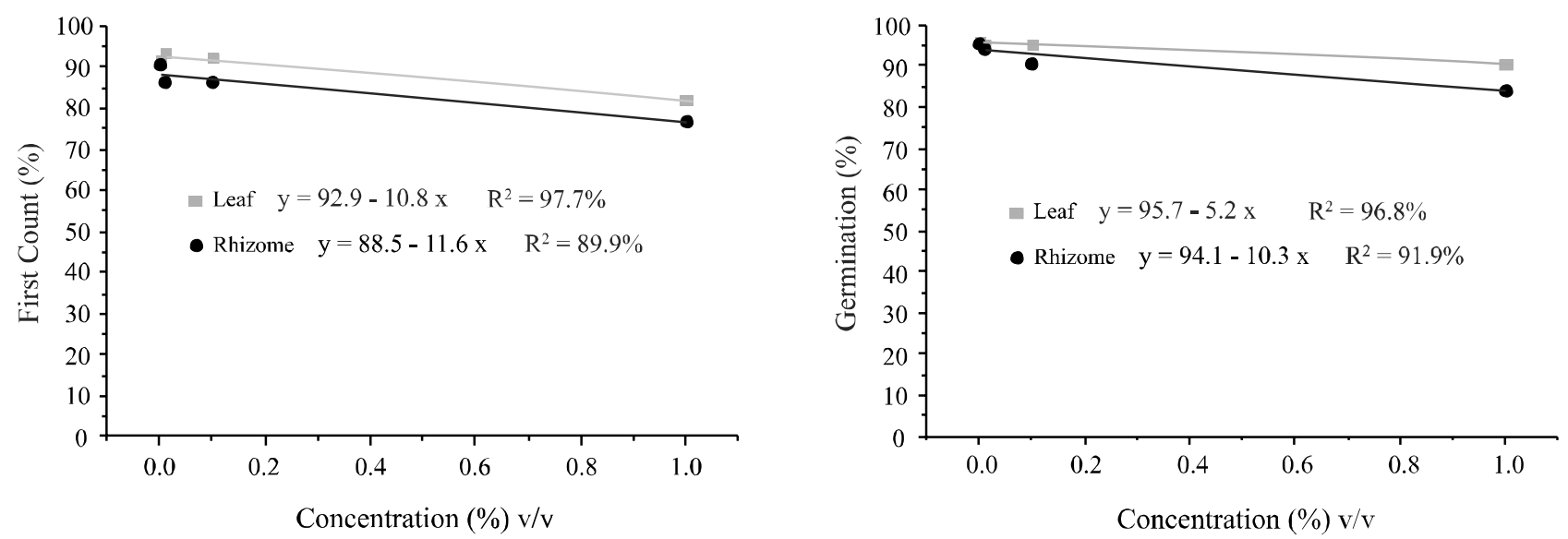
Figure 2 - Regression equations of the response variables GSI, seedling dry weight, root length and shoot length, for concentrations of essential oils extracted from the leaves and rhizomes of $H$. coronarium, evaluated with volatile-effect methodology
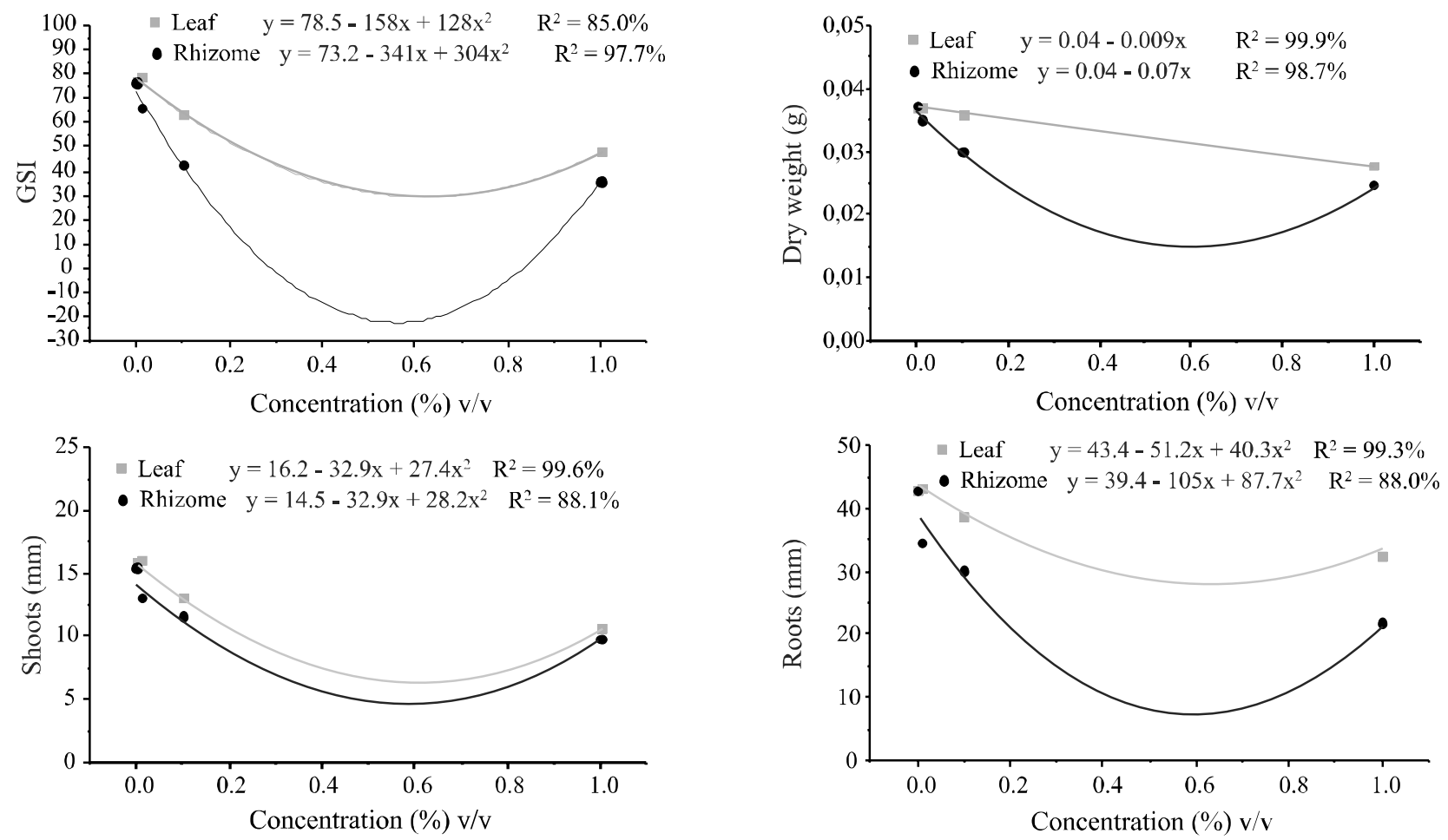

Figure 3 - Regression equations of the response variables first germination count and total germination, for concentrations of essential oils from the leaves and rhizomes of $H$. coronarium, evaluated with direct-contact methodology $(* \mathrm{NS}=\mathrm{Non}-$ Significant)
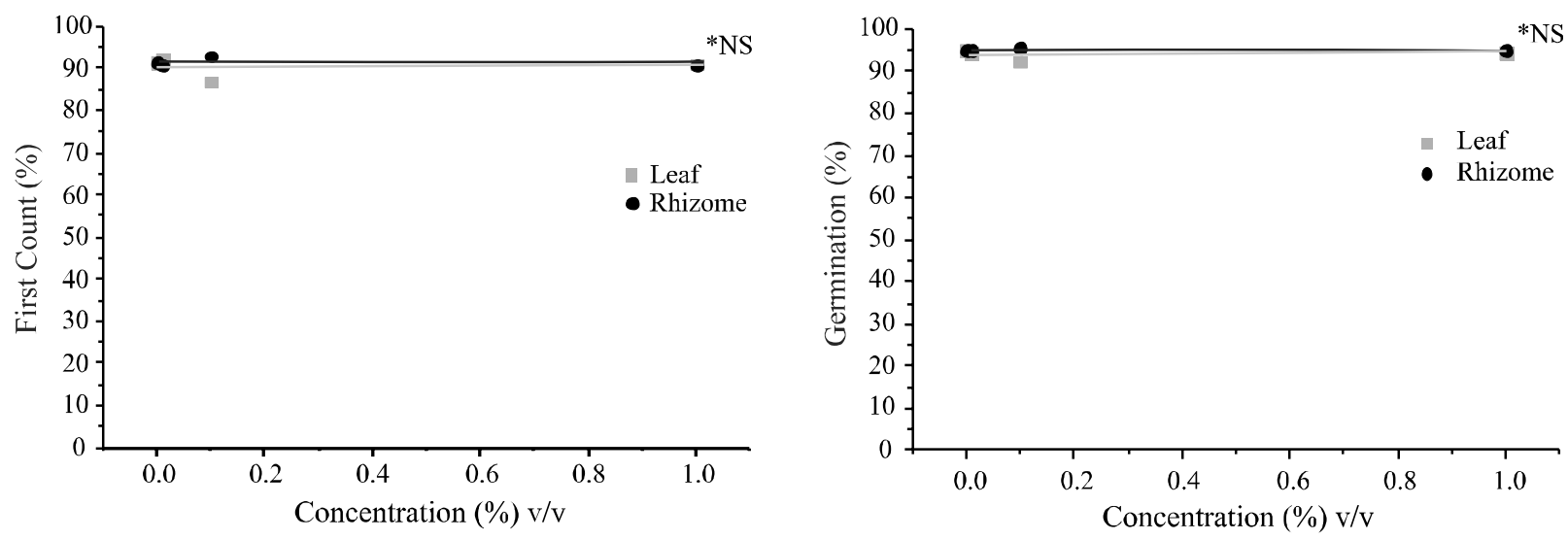

The variables GSI, dry weight, shoot length and root length of the seedlings showed a similar trend, with a reduction in value as the concentration of essential oils increased; the greater efficiency of the essential oil extracted from the rhizomes of $H$. coronarium in this reduction being further highlighted. A $1 \%$ concentration of the essential oil from the leaves reduced seedling

dry weight from 0.0370 to $0.0278 \mathrm{~g}$, SGI from 76.82 to 47.9 , shoot length from 18.5 to $10.7 \mathrm{~mm}$ and root length from 42.9 to $32.5 \mathrm{~mm}$. The same concentration of the oil from the rhizomes reduced these variables more efficiently, the dry weight from 0.0373 to $0.0248 \mathrm{~g}$, GSI from 76.57 to 36.07 , shoot length from 15.5 to $9.78 \mathrm{~mm}$ and root length from 43.0 to $21.8 \mathrm{~mm}$ (Figure 4). 
Figure 4 - Regression equations of the response variables SGI, seedling dry weight, shoot length and root length, for concentrations of essential oils from the leaves and rhizomes of $H$. coronarium, evaluated with direct-contact methodology $(*$ NS $=$ Non-Significant)
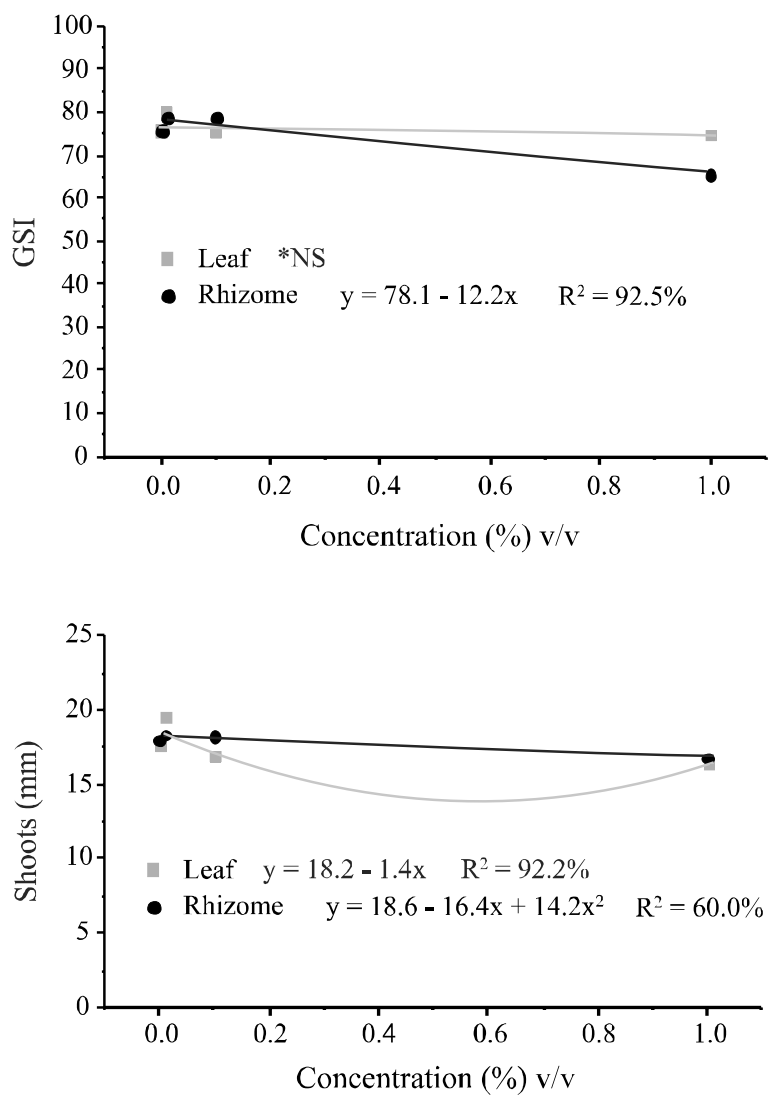

According to Souza Filho et al. (2009), the effects of essential oils on seedling germination and vigour can be explained on an individual basis by considering their major constituents, confirming the observations made in the present study, in which the composition of the essential oils extracted from different parts of $H$. coronarium influenced the differing inhibitory activities presented by these oils. The oil from the rhizomes showed $98.2 \%$ monoterpenes and $1 \%$ sesquiterpenes, whereas that from the leaves showed $84.3 \%$ monoterpenes and $14.9 \%$ sesquiterpenes. In addition, it was found that the essential oil from the rhizomes displayed a greater inhibitory effect than the oil extracted from the leaves, which may be explained by the higher monoterpene content. According to Rosado et al. (2009), the monoterpenes comprise the group of identified compounds with the greater inhibitory potential, as they cause changes in the structure and function of the membranes that prevent the growth and activity of the cells. In their studies, Duke, Romagni and Dayan (2000) state that among these monoterpene compounds, 1,8-cineole was shown to be effective in suppressing the growth of weeds, corroborating the data found in the present work, in which, among the chemical compounds of the oils under study, 1,8-cineole was only found to be a major
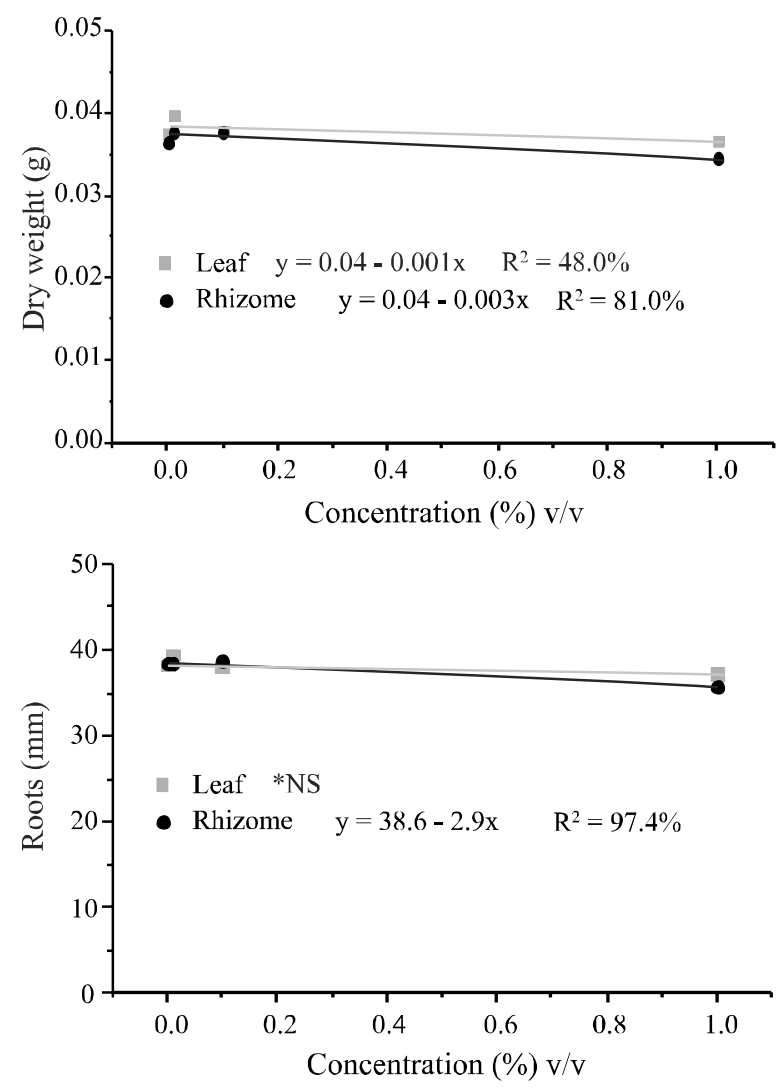

constituent in the essential oil from the rhizomes, which may explain its greater inhibitory and possible allelopathic effect.

\section{CONCLUSIONS}

1. Considering the limited effectiveness and high toxicity of synthetic herbicides traditionally employed in agriculture, the essential oil extracted from the rhizomes shows promise for future studies due to its higher allelopathic potential, since it displayed a greater inhibitory effect than the essential oil from leaves of the same species. This is possibly due to the higher percentage of monoterpene compounds, especially 1.8-cineole;

2. Further work that promotes isolation of the constituents of the oils under evaluation and clarification of the mechanisms of interaction between secondary metabolites and plant species will be essential for the development of new bioherbicides, possibly defining the ideal conditions for application of the essential oils and even the need for the isolation of, and research into their chemical constituents, either seperately or jointly. 


\section{ACKNOWLEDGEMENTS}

The authors wish to thank The National Council for Scientific and Technological Development (CNPq), the Foundation for Research Support of the State of Minas Gerais (FAPEMIG), the Coordination for the Training of Personnel in Higher Education (CAPES) and Pest-OE/EQB/LA0023/2011, for the support, financial help and scholarships granted.

\section{REFERENCES}

AGÊNCIA NACIONAL DE VIGILÂNCIA SANITÁRIA. Farmacopeia Brasileira. 5. ed. Brasília: ANVISA, 2010. p. 198-199.

BARBOSA, L. C. A. et al. Seasonal variation in the composition of volatile oils from Schinus terebinthifolius raddi. Química Nova, v. 30, n. 8, p. 1956-1965, 2007.

BRASIL. MINISTÉRIO DA AGRICULTURA E DA REFORMA AGRÁRIA. Regras para Análise de Sementes. Brasília: SNDA/DNDU/CLU, 2009. 399 p.

DUKE, S. O.; ROMAGNI, J. G.; DAYAN, F. E. Natural products as sources for new mechanisms of herbicidal action. Crop Protection, v. 19, n. 8, p. 583-589, 2000.

FERREIRA, D. F. Sisvar: a computer statistical analysis system. Ciência e Agrotecnologia, v. 35, n. 6, p. 1039-1042, 2011.

GOBBO-NETO, L.; LOPES, N. P. Plantas medicinais: fatores de influência no conteúdo de metabólitos secundários. Química Nova, v. 30, n. 2, p. 374-381, 2007.

KRZYZANOWSKI, F. C.; VIEIRA, R. D.; FRANÇA NETO, J. B. Vigor de sementes: conceitos e testes. Londrina: ABRATES, 1999. 218 p.

MAGUIRE, J. D. Speed of germination aid in selection and evaluation for seedling emergence and vigor. Crop Science, v. 2, n. 2, p. 176-177, 1962.

MARTINS, M. B. G. et al. Caracterização anatômica e fitoquímica de folhas e rizomas de Hedychium coronarium
J. König (Zingiberaceae). Revista Brasileira de Plantas Medicinais, v. 12, n. 2, p. 179-187, 2010.

MENDES, M. D. et al. ISSR molecular characterization and leaf volatiles analysis of Pittosporum undulatum Vent. naturalized in the Azores archipelago (Portugal). Industrial Crops and Products, v. 33, n. 3, p. 710-719, 2011.

PIMENTEL, F. A. et al. A convenient method for the determination of moisture in aromatic plants. Química Nova, v. 29, n. 2, p. 373-375, 2006.

PRAKASH, O. et al. Chemical Composition and antibacterial activity of rhizome oils from Hedychium coronarium Koenig and Hedychium spicatum Buch-Ham. Journal of Essential Oil-Bearing Plants, v. 13, n. 2, p. 250-259, 2010.

ROSADO, L. D. S. et al. Alelopatia do extrato aquoso e do óleo essencial de folhas do manjericão "Maria Bonita" na germinação de alface, tomate e melissa. Revista Brasileira de Plantas Medicinais, v. 11, n. 4, p. 422-428, 2009.

SANTOS, B. C. B. et al. Composition of leaf and rhizome essential oils of Hedychium coronarium Koen. from Brazil. Journal of Essential Oil Research, v. 22, n. 4, p. 305-306, 2010.

SANTOS, S. B.; PEDRALli, G.; MEYER, S. T. Aspectos da fenologia e ecologia de Hedychium coronarium (Zingiberaceae) na estação ecológica do Tripuí, Ouro PretoMG. Planta Daninha, v. 23, n. 2, p. 175-180, 2005.

SILVA, C. B. et al. Composição química e atividade alelopática do óleo volátil de Hydrocotyle bonariensis Lam (Araliaceae). Química Nova, v. 32, n. 9, p. 2373-2376, 2009.

SOUZA FILHO, A. P. S. et al. Análise comparativa do potencial alelopático do extrato hidroalcoólico e do óleo essencial de folhas de cipó-d'alho (Bignoniaceae). Planta Daninha, v. 27, n. 4, p. 647-653, 2009.

SOUZA FILHO, A. P. S. et al. Potencial alelopático de Myrcia guianensis. Planta Daninha, v. 24, n. 4, p. 649-656, 2006.

ZENNI, R. D.; ZILLER, S. R. An overview of invasive plants in Brazil. Revista Brasileira de Botânica, v. 34, n. 3, p. 431446, 2011. 